\title{
1 Exploration of a novel geoengineering solution: lighting up tropical forests at
} 2 night

3 Xueyuan $\mathrm{Gao}^{1}$, Shunlin Liang ${ }^{1 *}$, Dongdong Wang ${ }^{1}$, Yan $\mathrm{Li}^{2}, \mathrm{Bin}_{\mathrm{He}}^{3}$, Aolin $\mathrm{Jia}^{1}$

$4 \quad{ }^{1}$ Department of Geographical Sciences, University of Maryland, U.S.

$5 \quad{ }^{2}$ Faculty of Geographical Science, Beijing Normal University, China

$6{ }^{3}$ College of Global Change and Earth System Science, Beijing Normal University, China

$7 \quad *$ Corresponding author. Email: sliang@umd.edu

\section{Abstract}

9 Plants primarily conduct photosynthesis in the daytime, offering an opportunity to increase

10 photosynthesis and carbon sink by providing light at night. We used a fully coupled Earth

11 System Model to quantify the carbon sequestration and climate effects of a novel carbon removal

12 proposal: lighting up tropical forests at night via lamp networks above the forest canopy.

13 Simulation results show that additional light increased tropical forest carbon sink by $10.4 \pm 0.05$

14 petagrams of carbon per year during a 16-year lighting experiment, resulting in a decrease in

15 atmospheric $\mathrm{CO}_{2}$ and suppression of global warming. In addition, local temperature and

16 precipitation increased. The energy requirement for capturing one ton of carbon is lower than

17 that of Direct Air Carbon Capture. When the lighting experiment was terminated, tropical forests

18 started to release carbon slowly. This study suggests that lighting up tropical forests at night

19 could be an emergency solution to climate change, and carbon removal actions focused on

20 enhancing ecosystem productivity by altering environmental factors in the short term could

21 induce post-action $\mathrm{CO}_{2}$ outgassing.

\section{Short summary}

23 Numerical experiments with a coupled Earth System Model show that large-scale nighttime

24 artificial lighting in tropical forests will significantly increase carbon sink, local temperature, and 25 precipitation, and requires less energy than Direct Air Carbon Capture for capturing 1 ton 26 carbon, suggesting that it could be a powerful climate mitigation option. Side effects include the $27 \mathrm{CO}_{2}$ outgassing after the termination of the nighttime lighting and the impacts on local wildlife.

28 Keywords: climate change; Earth system model; geoengineering; carbon cycle; tropical forests 


\section{Introduction}

31 Anthropogenic greenhouse gas (GHG) emissions have led the global mean temperature to increase by approximately 1.1 degree Celsius since the industrial revolution(IPCC, 2013, 2018; IPCC AR6 WGI, 2021). Changes in climate have caused impacts on natural ecosystems and human societies, such as mass ice sheet melt(Jevrejeva et al., 2016), devastating heat waves(Dosio et al., 2018), and increase in extreme climate events(Kirchmeier-Young and Zhang, 2020), exposing natural and human systems to uncertainties and the risks of unsustainable development(Gao et al., 2019, 2020). Despite the scientific consensus on climate change, emission-reduction efforts have made slow or little progress with global GHG emissions continuing to rise(IPCC AR6 WGI, 2021). In this context, geoengineering options are increasingly being considered as means of deliberately intervening in Earth's climate system in the second half of the 21st century(IPCC AR6 WGI, 2021; Moore et al., 2015). Existing geoengineering proposals tend to align with two fundamentally different strategies: Solar Geoengineering (SG)(Abatayo et al., 2020; Proctor et al., 2018; Robock et al., 2009) and Carbon Capture and Sequestration (CCS)(IPCC, 2005; Jones, 2008; Leung et al., 2014). SG and related techniques reduce the amount of incoming radiation from the sun typically via stratospheric aerosol injection, subsequently affecting the planet's temperature. Although they may be able to offset temperature increase rapidly, previous studies indicate the potential for political instability(Abatayo et al., 2020) and negative impacts on human health(Robock et al., 2009) and agriculture(Proctor et al., 2018). Comparatively, CCS removes carbon from the global carbon cycle by artificial machines and saves it for long-term storage or for industrial reutilization(IPCC, 2005). While technically feasible, the environmental risks for the transport and storage of $\mathrm{CO}_{2}$, limited carbon storage capability, and high cost remain large obstacles of implementing CCS(IPCC, 2005; Jones, 2008; Leung et al., 2014). In this study, the authors propose a novel geoengineering solution: lighting up tropical forests at night by installing lamp networks above the forest canopy(Graham et al., 2003), which lengthens photoperiods and leads to greater photosynthesis and carbon sequestration, and helps mitigate climate change. Contrasting to traditional CCS techniques, this strategy utilizes nature carbon

58 sink to capture and sequester $\mathrm{CO}_{2}$ from air and avoids long-distance transport and geological 59 storage.

60 Structurally intact tropical forests are by far the most efficient carbon-capture method(Mitchard, 61 2018), and they act as an important carbon sink against rising $\mathrm{CO}_{2}$ levels(Pan et al., 2011; 
62 Sullivan et al., 2020). Although intact tropical forest growth is likely suffering from warming

63 and moisture stress induced by anthropogenic greenhouse gas emissions(Aguirre-Gutiérrez et al.,

64 2020; Doughty et al., 2015; Gatti et al., 2021; Hubau et al., 2020), light is still the primary factor

65 limiting tropical tree growth due to cloud cover, especially during the rainy season(Boisvenue

66 and Running, 2006; Graham et al., 2003). Previous studies have shown that longer photoperiods

67 facilitate the bud break and flowering in tropical forests(Borchert et al., 2005; Rivera et al.,

68 2002). A greenhouse study in 1978 showed that a tropical tree species grown for one year under

69 a 15-hour photoperiod treatment had an average stem length twice that of the same species

70 grown under an 8-hour photoperiod treatment(Stubblebine et al., 1978). These studies suggest

71 that longer photoperiods might have a positive effect on vegetative growth in tropical forests.

72 Earth System Models provides state-of-the-art computer simulations of key processes and climate states across the Earth(Danabasoglu et al., 2020). In this study the authors used a fully coupled Earth System Model, Community Earth System Model version 2 (CESM2) developed by the U.S. National Center for Atmospheric Research(Danabasoglu et al., 2020), to test the carbon sequestration and climate effects of this geoengineering measure by conducting numerical lighting experiments. Briefly, we added additional diffuse visible light to tropical forest canopy at night (see Supplementary Figure 1) assuming that trees will receive light from multiple directions (e.g., multiple lamps). Tropical forest grids were defined by "Broadleaf Evergreen Tree Area Percentage" being greater than $60 \%$ between $20^{\circ} \mathrm{N}$ and $20^{\circ} \mathrm{S}$. The lighting experiment started from 12:00 am on January $1^{\text {st }}, 2015$ (UTC time), and the simulation exercise was conducted across numerous timescales and lighting levels:

(1) Historical control simulation from 2001 to 2014

(2) 24-hour lighting experiment with various lighting powers on January $1^{\text {st }}, 2015$

(3) 16-year lighting experiment with the optimal lighting power from 2015 to 2030

(4) 20-year simulation after the experiment termination from 2031 to 2050

(5) Future control simulation from 2015 to 2050

Both experiment and control simulations in the future from 2015 to 2050 were on top of the Shared Socioeconomic Pathways (SSP) 126 scenario(Riahi et al., 2017). Each simulation has a spatial resolution of $1^{\circ}$ and has two members (created from small perturbations to initial conditions) to provide uncertainty estimation. (see Methods for detailed experimental design) 


\section{2. Results}

94 2.1 24-hour lighting experiment with various lighting powers on January $1^{\text {st }} 2015$

95 Figure 1 shows the changes in carbon and energy fluxes of Amazonian tropical forests for 24

96 hours since the start of the nighttime lighting experiment at 12:00 am January ${ }^{\text {st }}$, 2015 (UTC

97 time; See Supplementary Figure 2 and 3 for African and Asian tropical forest responses).

98 Tropical forests had a significant response to nighttime radiation, but the response was different

99 under 100, 200, 300, and $400 \mathrm{~W} / \mathrm{m}^{2}$ lighting powers. The lighting experiment altered the

100 nighttime energy balance and increased near surface air temperature, latent heat, and sensible

101 heat. Higher lighting powers led to greater increases in air temperature, latent heat and sensible

102 heat. Meanwhile, the additional light activated photosynthesis and increased Net Ecosystem

103 Productivity (NEP). Nighttime NEP reached the peak at $200 \mathrm{~W} / \mathrm{m}^{2}$ and seemed to be suppressed

104 when the lighting power was higher. Comparison of NEP across lighting powers suggests that

$105200 \mathrm{~W} / \mathrm{m}^{2}$ is optimal in terms of activating additional photosynthesis. African and Asian tropical

106 forests showed similar responses. 
108 Fig. 1. Amazonian tropical forest responses for 24 hours since the start of the nighttime lighting 109 experiment at 12:00 am January 1st, 2015 (UTC time) under various nighttime lighting powers.

110 Panel (a) refers to surface downward shortwave radiation. Nighttime NEP (b) reached the peak at $111200 \mathrm{~W} / \mathrm{m}^{2}$, suggesting that $200 \mathrm{~W} / \mathrm{m}^{2}$ is optimal in terms of activating additional photosynthesis.

112
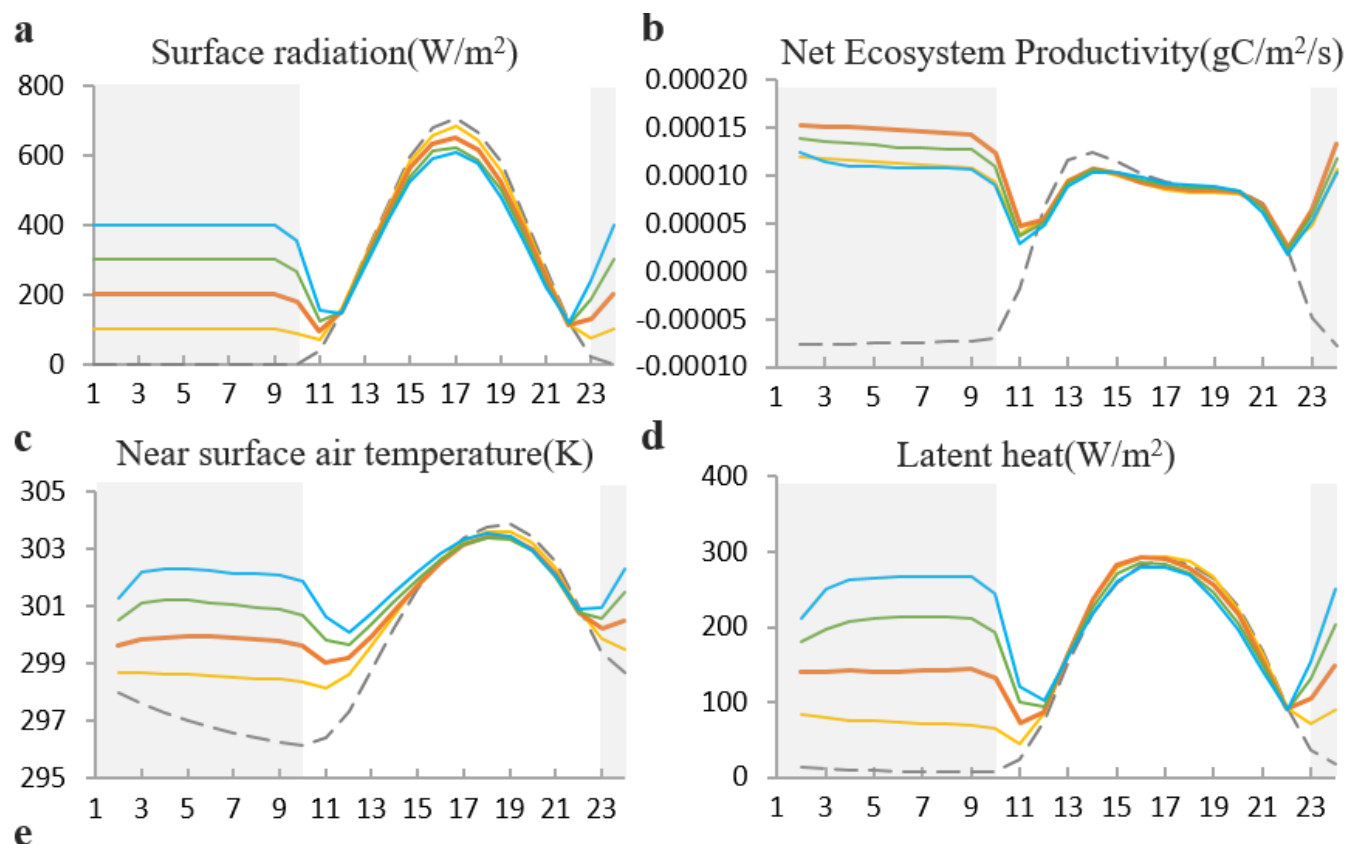

d

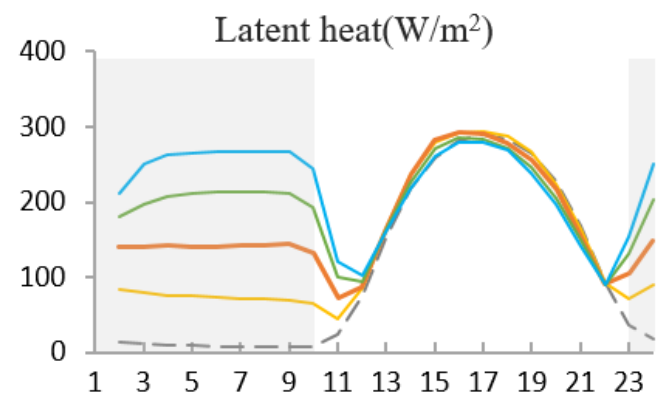

e Sensible heat $\left(\mathrm{W} / \mathrm{m}^{2}\right)$
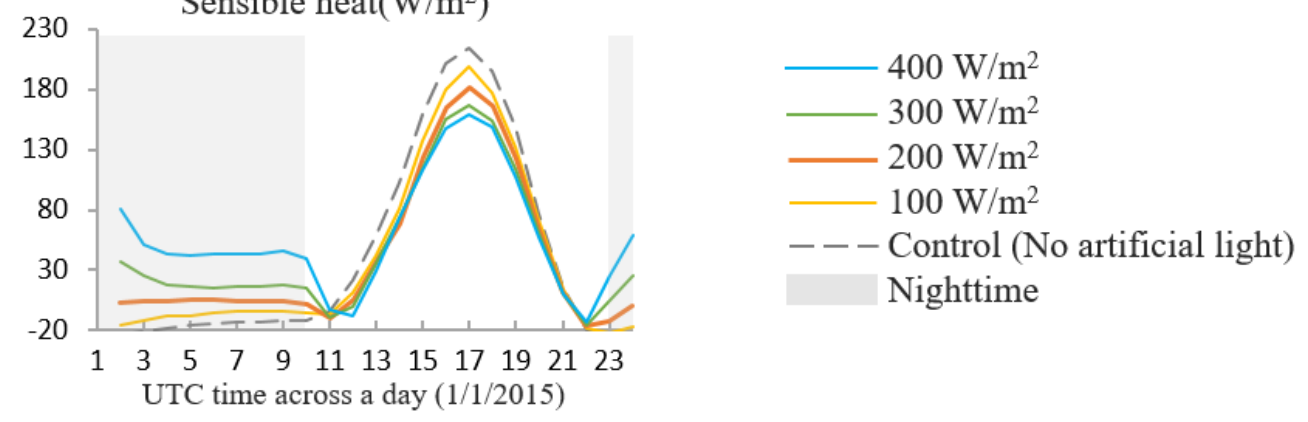
113 2.2 16-year lighting experiment with the optimal lighting power from 2015 to 2030

114 The yellow lines in Figure 2 show that tropical forest carbon fluxes and climates were

115 significantly altered by a 16 -year continuous lighting experiment at night with a $200 \mathrm{~W} / \mathrm{m}^{2}$

116 power. The annual gross primary production and autotrophic respiration increased by twice near

117 instantaneously, while the heterotrophic respiration had a slower response and increased

118 continuously over a longer period. We purport these changes to be due to the increase in local

119 temperature and the gradual accumulation of organic matter in the soil. Simulation results show

120 that the lighting experiment also decreased wildfire emissions. However, the expansion of the coarse woody debris and litter carbon pool could provide more burning materials and increase wildfire risks. Overall, the net carbon uptake increased to around 25 petagrams of carbon per year $\left(\mathrm{Pg} \mathrm{C} \mathrm{yr}^{-1}\right)$ in the beginning of the lighting experiment, although it decreased with time due to the continuous increase in heterotrophic respiration. The lighting experiment increased the net carbon uptake in tropical forests by 15.3 times over the simulation period (from $0.68 \pm 0.02 \mathrm{Pg} \mathrm{C}$ $\mathrm{yr}^{-1}$ over 2001-2014 to $11.1 \pm 0.05 \mathrm{Pg} \mathrm{C} \mathrm{yr}^{-1}$ over 2015-2030). Among all the absorbed carbon, $75 \%$ entered the vegetation carbon pool, $16 \%$ entered the coarse woody debris and litter carbon pool, and $9 \%$ entered the soil carbon pool (Figure 3-b).

Simulation results show that local climates were also significantly impacted (Figure 2-g,h). The annual average air temperature increased by around $1.3^{\circ} \mathrm{C}$, and annual precipitation almost doubled. The temperature and precipitation increase showed no significant seasonal trend (Supplementary Figure 4). Globally, the atmospheric $\mathrm{CO}_{2}$ concentration dropped quickly in the first several years, while turned flat in the latter of the lighting experiment. As a result, the global average air temperature increase was suppressed by around $0.5^{\circ} \mathrm{C}$.

Amazonian, African, and Asian tropical forests present different capabilities to offset annual atmospheric carbon accumulation during the lighting experiment (Figure 4). In the current global carbon budget(Friedlingstein et al., 2019) (averaged from 2009 to 2018), approximately $11 \pm 0.5$

$138 \mathrm{Pg} \mathrm{C} \mathrm{yr}^{-1}$ was released into atmosphere by anthropogenic activities including fossil fuel combustion and land use, among which $2.5 \pm 0.6 \mathrm{Pg} \mathrm{C} \mathrm{yr}^{-1}$ was absorbed by ocean, $3.2 \pm 0.6 \mathrm{Pg} \mathrm{C}$ $\mathrm{yr}^{-1}$ was absorbed by land, and $4.9 \pm 0.02 \mathrm{Pg} \mathrm{C} \mathrm{yr}^{-1}$ was accumulated in atmosphere resulting in the concerned warming and climate change. The lighting experiment enhanced Amazonian tropical forest net carbon uptake to 6.5 $\pm 0.04 \mathrm{Pg} \mathrm{C} \mathrm{yr}^{-1}$ (averaged during 2015 to 2030),

143 suggesting that lighting up Amazonian tropical forests along could completely offset 144 anthropogenic carbon emissions. African and Asian tropical forests showed lower capabilities 
145 with the net carbon uptake being approximately $2.0 \pm 0.002$ and $2.6 \pm 0.008 \mathrm{Pg} \mathrm{C} \mathrm{yr}^{-1}$ respectively

146 (see Supplementary Figure 5, 6, and 7 for Amazonian, African, and Asian tropical forest carbon

147 flux, carbon amount, and climate responses respectively).

148 
149 Fig. 2. Global tropical forest carbon flux and climate responses under and after the lighting

150 experiment. Ta in panel $(g \& \mathrm{j})$ : Near surface air temperature. Shaded areas represent

151 uncertainties, except those in panel (f) which denote carbon released back to atmosphere after the

152 termination of the lighting experiment.
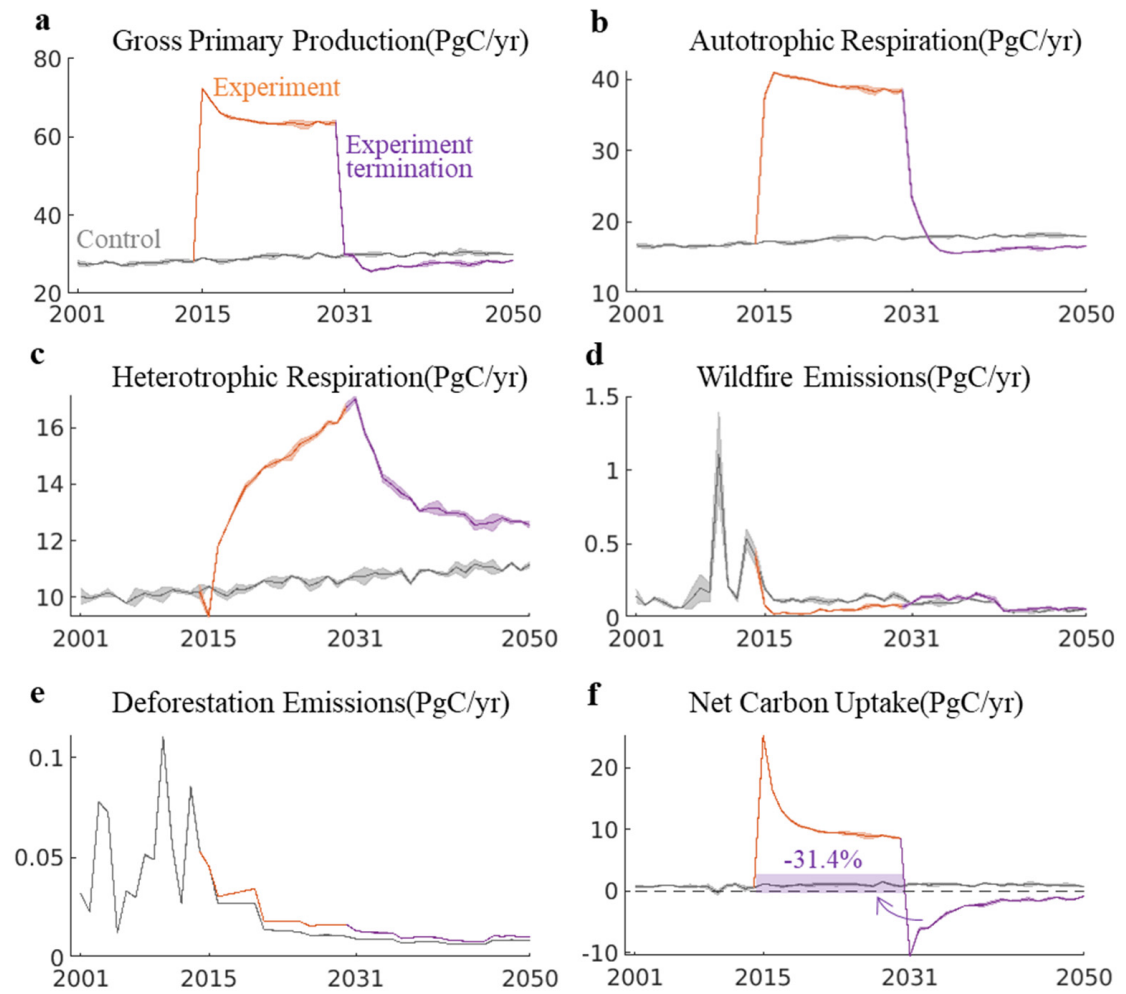

f Net Carbon Uptake(PgC/yr)
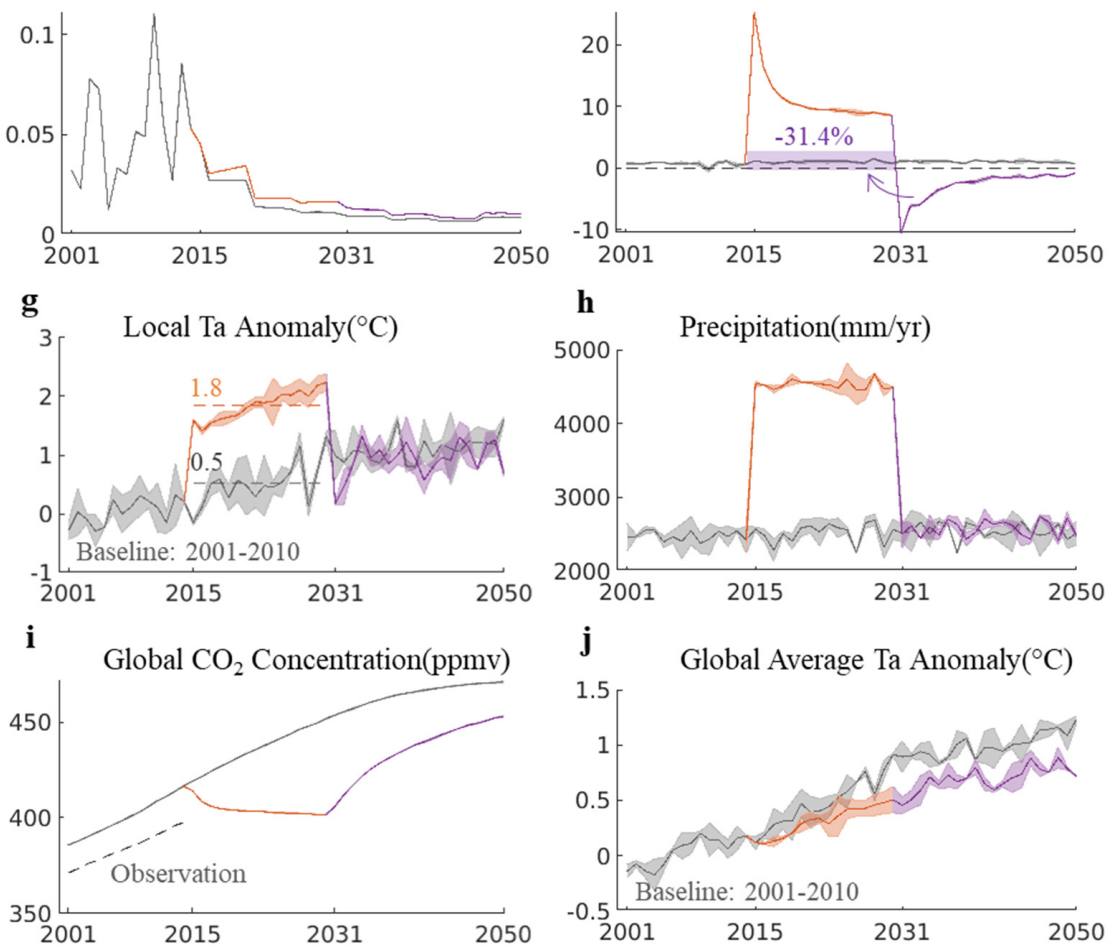

years since the termination of the lighting experiments. The solid circles in panel (b) and (c) refer to carbon amount changes with respect to panel (a). The numbers in panels (a-c) are based on panels (d-f). Tree drawing courtesy of $\mathbb{C}$ Ning Zeng.

a. 2014

Vegetation carbon pool

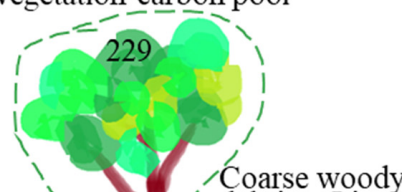

Coarse woody debris + Litter / (CL) carbon poo

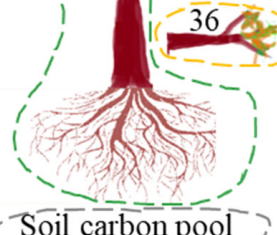

Soil carbon pool

d

Total Vegetation Carbon

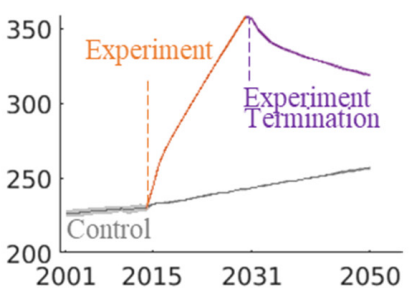

b.2030

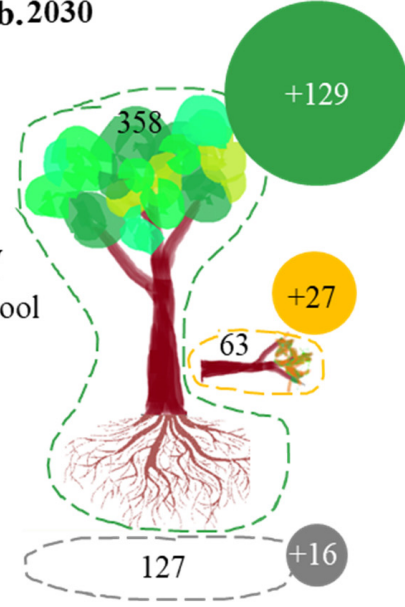

e

Total CL Carbon

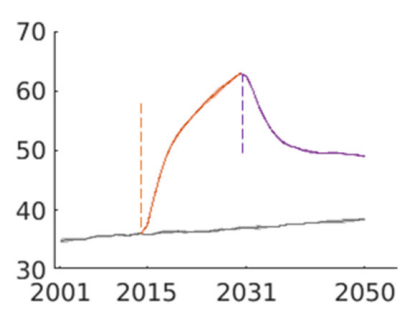

c. 2050

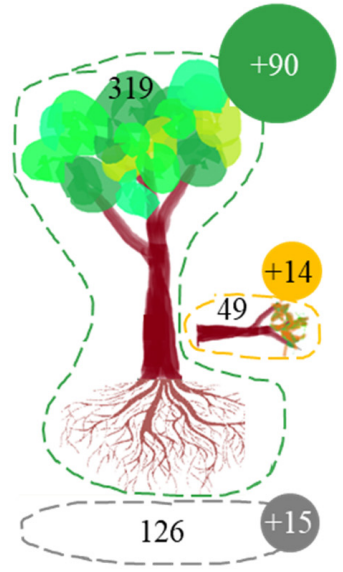

f Total Soil Organic Matter

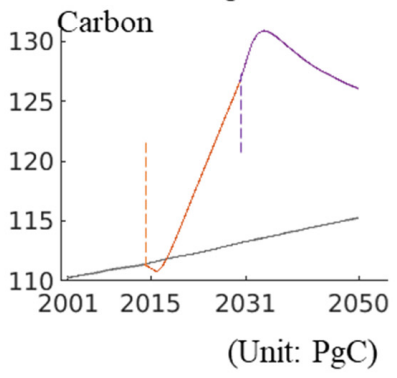


161 Fig. 4. Capabilities of Amazonian, African, and Asian tropical forests to offset annual

162 atmospheric carbon accumulation.

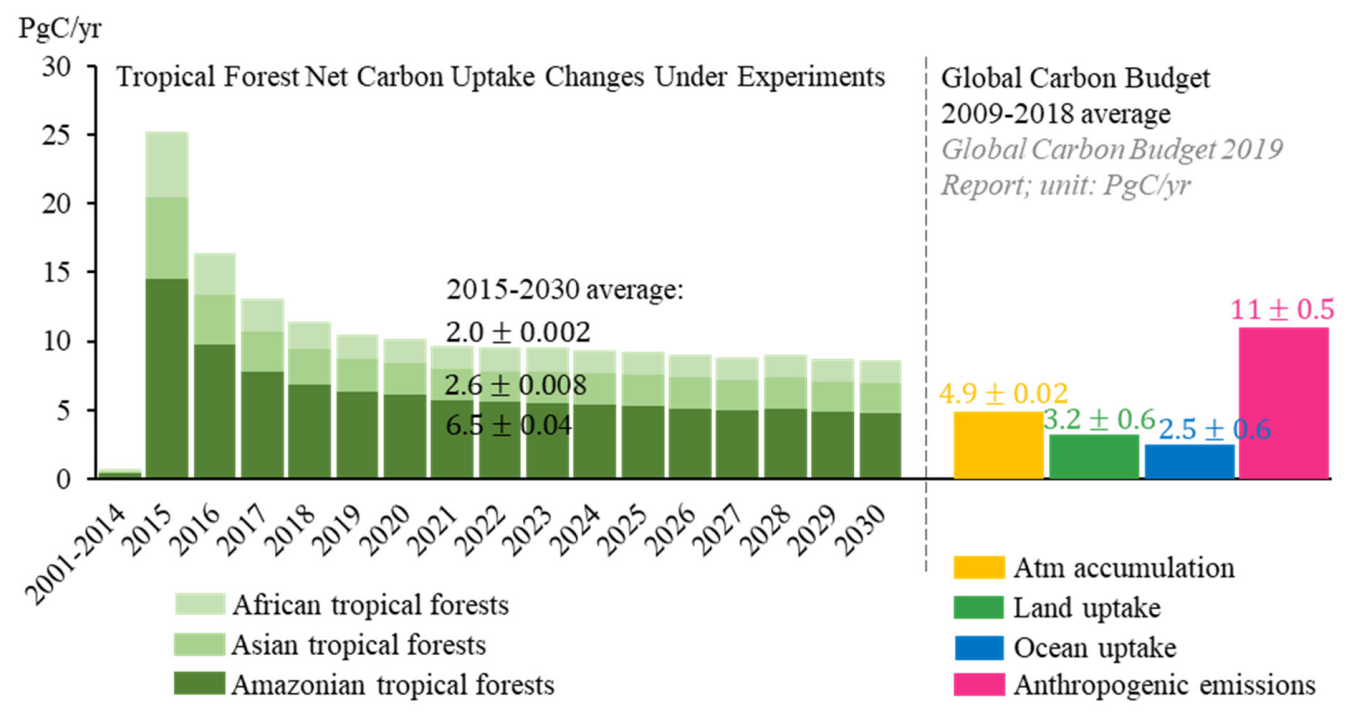

165 We estimated the energy requirement of this strategy for capturing one ton of carbon, and

166 compared it to that of Direct Air Carbon Capture (DACC) estimated by recent studies(Chatterjee

167 and Huang, 2020; Realmonte et al., 2019). As the carbon uptake efficiency of the tropical forest

168 ecosystem decreases with time when under consecutive nighttime lighting, the energy

169 requirement for capturing one ton of carbon increases (Figure 5 purple line). Nevertheless, the

170 energy requirement of this strategy is lower than that of DACC, or is equivalent to the most

171 optimistic estimation of DACC's energy requirement that excludes the energy costs required for 172 carbon transport, storage, and utilization. 
174 Figure 5. Energy requirement for DACC and the nighttime lighting strategy

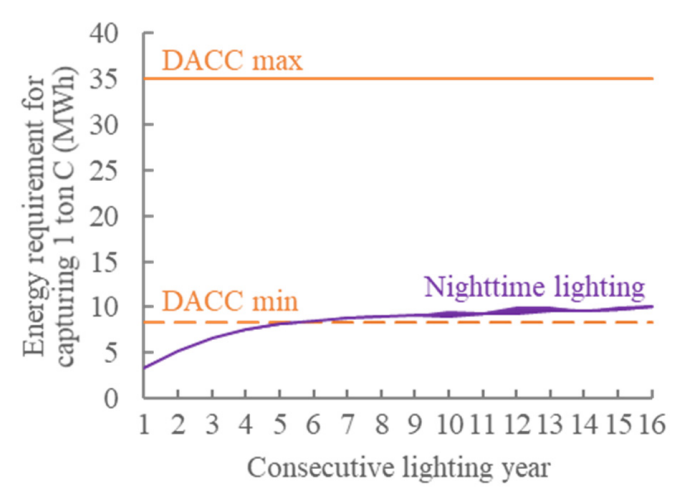

175

1762.320 -year simulation after the experiment termination from 2031 to 2050

177 The lighting experiment was terminated at 12:00 am January $1^{\text {st }}, 2031$ (UTC time), and model

178 simulations continued for 20 years to 2050 (see the purple lines in Figure 2). The annual gross

179 primary production and autotrophic respiration dropped quickly, ultimately reaching levels that

180 were even lower than the control period due to a reduction in atmospheric $\mathrm{CO}_{2}\left(\mathrm{CO}_{2}\right.$ has

181 fertilization effect in the model). Heterotrophic respiration remained high and decreased much

182 slower at a speed 10 times lower than gross primary production and autotrophic respiration. The

183 soil organic matter carbon pool continued to expand due to the entering of litter carbon during

184 the first 2-3 years following the experiment termination (Figure 3-f). The vegetation carbon pool

185 shrunk as trees produced less leaves (Figure 3-d). As a result, tropical forests turned into a net

186 carbon source and remained so until the end of the simulation in 2050 (Figure 2-f). $31.4 \%$ of the

187 carbon that had been absorbed during the lighting experiment was released back to the

188 atmosphere. This number would likely be higher if the simulation continued. As a result, the

189 global atmospheric $\mathrm{CO}_{2}$ concentration returned to a level slightly lower than the control scenario.

190 Local air temperature and precipitation returned to control levels. 


\section{Discussion}

193 Physiological responses of tropical trees to near 24-hour photoperiods at the ecosystem level remains one of the biggest uncertainties in model simulations. Some field experiments indicate that higher $\mathrm{CO}_{2}$ did not increase carbon sequestration of forests without added nutrients(Oren et al., 2001), suggesting tree growth might be limited by nutrient supply. The simulated local warming might also suppress tree growth(Gatti et al., 2021). Some observational evidence shows that intact tropical forest carbon sinks have been negatively influenced by warming and moisture stress(Doughty et al., 2015; Gatti et al., 2021) and might be reaching saturation(Hubau et al., 2020). However, the model predicted increase in precipitation, and previous studies have shown hydro climate plays a key role in deciding the effects of warming on tree growth(Guan et al., 2015; Reich et al., 2018). No direct evidence exists to verify the simulation results. Ecosystemlevel field experiments are needed to understand how tropical forest ecosystems respond to longer photoperiods.

CESM2 likely overestimated the local air temperature increase in tropical forests for the omission of chemical energy stored during photosynthesis(Sellers, 1992). In CESM2 and other modern Earth System Models(Sellers, 1992), the canopy energy equation(Danabasoglu et al., 2020) uses the solar radiation absorbed by the vegetation to calculate temperature:

$$
-\vec{S}_{v}+\vec{L}_{v}\left(T_{v}\right)+H_{v}\left(T_{v}\right)+\lambda E_{v}\left(T_{v}\right)=0
$$

210 where $\vec{S}_{v}$ is the solar radiation absorbed by the vegetation, $\vec{L}_{v}$ is the net longwave radiation

211 absorbed by vegetation, and $H_{v}$ and $\lambda E_{v}$ are the sensible and latent heat fluxes from vegetation,

212 respectively. $\vec{L}_{v}, H_{v}$, and $\lambda E_{v}$ depend on the vegetation temperature $T_{v}$.

213 The chemical energy that is stored during photosynthesis and released by respiration is ignored

214 as the net chemical energy usually amounts to less than $1 \%$ of absorbed insolation (around

$2150.6 \%$ (Trenberth et al., 2009)). In our lighting experiment from 2015 to 2030 , however, $17 \%$ of

216 absorbed insolation was fixed in the ecosystem as chemical energy (Figure 2-f) and did not

217 contribute to local air temperature increase. The model failed to exclude this chemical energy

218 storage from the energy equation. Therefore, the model overestimated the local temperature

219 increase. This suggests that the temperature simulation results should be treated carefully when

220 Earth System Models are used to do extreme scenario experiments associated with

221 biogeochemistry. 
222 Tropical forests experienced significant increase in carbon sink during the lighting experiment,

223 but ultimately transitioned from a sink to a source after the experiment was terminated (Figure 2-

224 f). Studies(Koven et al., 2021; Tokarska and Zickfeld, 2015) investigating the effects of

225 overshoot future scenarios (positive carbon emissions followed by net-negative emissions) on

226 terrestrial carbon cycle have observed similar phenomenon. During a positive emissions phase,

227 terrestrial carbon cycles tend to absorb some fraction of added $\mathrm{CO}_{2}$; however, during a removal

228 phase they tend to release $\mathrm{CO}_{2}$. The mechanism of these phenomena is the different responding

229 rates of vegetative primary productivity and heterotrophic respiration to lengthening and

230 shortening photoperiods, or increasing and decreasing atmospheric $\mathrm{CO}_{2}$, with primary

231 productivity responding much quicker than heterotrophic respiration. It is understandable when

232 considering the diurnal pattern of forest carbon uptake. In the daytime, forests act as a carbon

233 sink because photosynthesis is greater than respiration. In the nighttime respiration continues

234 while photosynthesis abates, making forests a carbon source. Additional light $/ \mathrm{CO}_{2}$ would

235 increase carbon sink by increasing both photosynthesis and respiration (sometimes referred to as

236 a fertilization effect). When the additional light $/ \mathrm{CO}_{2}$ is removed, photosynthesis decreases

237 quickly while respiration remains high, making forests a greater carbon source. It suggests that

238 carbon removal actions focused on enhancing ecosystem productivity by altering environmental

239 factors in the short term could induce this post-action $\mathrm{CO}_{2}$ outgassing.

240 Overall, lighting up tropical forests at night has led to significant increase in carbon uptakes,

241 decrease in atmospheric $\mathrm{CO}_{2}$ concentration, and suppression of global warming as simulated by

242 Earth System Model. However, it has strong side effects after the termination of nighttime

243 lighting. In addition, local ecosystem changes could have negative impacts on local wildlife.

244 Practical issues include the large demand for clean energy and the difficulties for

245 implementation. From a positive standing it might be treated as an emergency climate solution if

246 the society relies heavily on carbon removal to adjust the Earth's climate in the future. Paris

247 Agreement set climate goals to limit global warming to well below 2 degree Celsius and

248 preferably to 1.5 degree Celsius compared to pre-industrial levels(Lawrence et al., 2018). To

249 accomplish the Paris Agreement's climate goals, different engineering levels (lighting powers,

250 areas, and periods) might be needed under various anthropogenic emission scenarios, with high-

251 emission scenarios possibly requiring high engineering levels. This study investigated the highest

252 engineering level (lighting up global tropical forests at night with the optimal power) under a

253 low-emission scenario (see Methods). Further research is needed to investigate the relationship 
254 between engineering levels and emission scenarios in the context of global climate goals set out

255 by the Paris Agreement(Lawrence et al., 2018).

256 Current geoengineering studies mainly focus on the evaluation of climate goals that a potential

257 solution might or might not accomplish; however, the changes in Earth's climate after

258 terminating a geoengineering measure tend to be overlooked. This study suggests the importance

259 of post-geoengineering analysis in geoengineering studies.

\section{4. Methods}

261 The CESM2 is an open-source community coupled model consisting of atmosphere, ocean, land, 262 sea-ice, land-ice, river, and wave models that exchange states and fluxes via a

263 coupler(Danabasoglu et al., 2020). In this study, we used standard CESM2 configurations and

264 enabled all modules including the Community Atmosphere Model version 6 (CAM6), the

265 Parallel Ocean Program version 2 (POP2) with an ocean biogeochemistry component, the

266 Community Land Model version 5 (CLM5) with a land biogeochemistry component, CICE

267 version 5.1.2 (CICE5), the Community Ice Sheet Model Version 2.1 (CISM2.1), the Model for

268 Scale Adaptive River Transport (MOSART), and the NOAA WaveWatch-III ocean surface wave

269 prediction model version 3.14 (WW3). The CESM2 is part of the Couple Model Intercomparison

270 Project Phase 6 (CMIP6) core simulations as well as about 20 Model Intercomparison Projects

271 (MIPs) within CMIP6. Extensive evaluation suggests that the CESM2 simulations exhibit

272 agreement with satellite era observations of the climate mean state, seasonal cycle, and

273 interannual variability, which has identified CESM2 as among the most realistic climate models

274 in the world(Danabasoglu et al., 2020).

275 4.1 Historical Control Simulation from 2001 to 2014

276 CESM2 has published its official historical simulation datasets from 1850-2014 on the Earth

277 System Grid Federation (ESGF; https://esgf-node.llnl.gov/search/cmip6). This study analyzed

278 the historical simulation datasets of two members from 2001 to 2014 produced by the CESM2

279 esm-hist-BPRP case.

280 4.2 Future Experiment and Control Simulations from 2015 to 2050

281 The selection of 2015 as the start year of the lighting experiment follows CMIP6 future scenario

282 simulation rules. The future experiment simulations and control simulations were both based on

283 the Shared Socioeconomic Pathways (SSP) 126 scenario(Riahi et al., 2017), which is a low-

284 emission (low fossil fuel combustion and deforestation) scenario. The Earth's climate state under 


\section{Code and Data Availability}

314 CESM2 is an open-source community climate model preserved at

315 https://doi.org/10.1029/2019MS001916. All data have been included in the manuscript.

\section{Author contribution}

317 XG designed the study and performed the simulations. XG, SL, DW, YL, BH, and AJ

318 contributed to the data interpretation. XG drafted the original version of the manuscript. SL and

319 DW reviewed and edited the manuscript.

\section{Competing interests}

321 Authors declare that they have no competing interests.

\section{Acknowledgments}

323 We would like to acknowledge high-performance computing support from Cheyenne

324 (doi:10.5065/D6RX99HX) provided by NCAR's Computational and Information Systems

325 Laboratory, sponsored by the National Science Foundation. We would like to acknowledge the

326 constructive comments and suggestions from William Wieder.

\section{References}

328 Abatayo, A. Lou, Bosetti, V., Casari, M., Ghidoni, R. and Tavoni, M.: Solar geoengineering may 329 lead to excessive cooling and high strategic uncertainty, Proc. Natl. Acad. Sci. U. S. A., 117(24), 330 doi:10.1073/pnas.1916637117, 2020.

331 Aguirre-Gutiérrez, J., Malhi, Y., Lewis, S. L., Fauset, S., Adu-Bredu, S., Affum-Baffoe, K.,

332 Baker, T. R., Gvozdevaite, A., Hubau, W., Moore, S., Peprah, T., Ziemińska, K., Phillips, O. L.

333 and Oliveras, I.: Long-term droughts may drive drier tropical forests towards increased

334 functional, taxonomic and phylogenetic homogeneity, Nat. Commun., 11(1),

335 doi:10.1038/s41467-020-16973-4, 2020.

336 Boisvenue, C. and Running, S. W.: Impacts of climate change on natural forest productivity -

337 Evidence since the middle of the 20th century, Glob. Chang. Biol., 12(5), doi:10.1111/j.1365-

$338 \quad 2486.2006 .01134 . x, 2006$.

339 Borchert, R., Renner, S. S., Calle, Z., Havarrete, D., Tye, A., Gautier, L., Spichiger, R. and Von

340 Hildebrand, P.: Photoperiodic induction of synchronous flowering near the Equator, Nature,

341 433(7026), doi:10.1038/nature03259, 2005. 
342 Chatterjee, S. and Huang, K. W.: Unrealistic energy and materials requirement for direct air 343 capture in deep mitigation pathways, Nat. Commun., 11(1), doi:10.1038/s41467-020-17203-7, 3442020.

345 Danabasoglu, G., Lamarque, J. F., Bacmeister, J., Bailey, D. A., DuVivier, A. K., Edwards, J., 346 Emmons, L. K., Fasullo, J., Garcia, R., Gettelman, A., Hannay, C., Holland, M. M., Large, W. 347 G., Lauritzen, P. H., Lawrence, D. M., Lenaerts, J. T. M., Lindsay, K., Lipscomb, W. H., Mills, 348 M. J., Neale, R., Oleson, K. W., Otto-Bliesner, B., Phillips, A. S., Sacks, W., Tilmes, S., van 349 Kampenhout, L., Vertenstein, M., Bertini, A., Dennis, J., Deser, C., Fischer, C., Fox-Kemper, B., 350 Kay, J. E., Kinnison, D., Kushner, P. J., Larson, V. E., Long, M. C., Mickelson, S., Moore, J. K., 351 Nienhouse, E., Polvani, L., Rasch, P. J. and Strand, W. G.: The Community Earth System Model 352 Version 2 (CESM2), J. Adv. Model. Earth Syst., 12(2), doi:10.1029/2019MS001916, 2020.

353 Dosio, A., Mentaschi, L., Fischer, E. M. and Wyser, K.: Extreme heat waves under $1.5^{\circ} \mathrm{c}$ and $3542{ }^{\circ} \mathrm{c}$ global warming, Environ. Res. Lett., 13(5), doi:10.1088/1748-9326/aab827, 2018.

355 Doughty, C. E., Metcalfe, D. B., Girardin, C. A. J., Amézquita, F. F., Cabrera, D. G., Huasco, W. 356 H., Silva-Espejo, J. E., Araujo-Murakami, A., Da Costa, M. C., Rocha, W., Feldpausch, T. R., 357 Mendoza, A. L. M., Da Costa, A. C. L., Meir, P., Phillips, O. L. and Malhi, Y.: Drought impact 358 on forest carbon dynamics and fluxes in Amazonia, Nature, 519(7541), 359 doi:10.1038/nature14213, 2015.

360 Friedlingstein, P., Jones, M. W., O’Sullivan, M., Andrew, R. M., Hauck, J., Peters, G. P., Peters, 361 W., Pongratz, J., Sitch, S., Le Quéré, C., DBakker, O. C. E., Canadel11, J. G., Ciais1, P., Jackson, 362 R. B., Anthoni1, P., Barbero, L., Bastos, A., Bastrikov, V., Becker, M., Bopp, L., Buitenhuis, E., 363 Chandra, N., Chevallier, F., Chini, L. P., Currie, K. I., Feely, R. A., Gehlen, M., Gilfillan, D.,

364 Gkritzalis, T., Goll, D. S., Gruber, N., Gutekunst, S., Harris, I., Haverd, V., Houghton, R. A., 365 Hurtt, G., Ilyina, T., Jain, A. K., Joetzjer, E., Kaplan, J. O., Kato, E., Goldewijk, K. K., 366 Korsbakken, J. I., Landschützer, P., Lauvset, S. K., Lefèvre, N., Lenton, A., Lienert, S., 367 Lombardozzi, D., Marland, G., McGuire, P. C., Melton, J. R., Metzl, N., Munro, D. R., Nabel, J. 368 E. M. S., Nakaoka, S. I., Neill, C., Omar, A. M., Ono, T., Peregon, A., Pierrot, D., Poulter, B., 369 Rehder, G., Resplandy, L., Robertson, E., Rödenbeck, C., Séférian, R., Schwinger, J., Smith, N., 370 Tans, P. P., Tian, H., Tilbrook, B., Tubiello, F. N., Van Der Werf, G. R., Wiltshire, A. J. and 371 Zaehle, S.: Global carbon budget 2019, Earth Syst. Sci. Data, 11(4), doi:10.5194/essd-11-1783$3722019,2019$. 
373 Gao, X., Liang, S. and He, B.: Detected global agricultural greening from satellite data, Agric.

374 For. Meteorol., 276-277, doi:10.1016/j.agrformet.2019.107652, 2019.

375 Gao, X., Liang, S. and Sauer, J.: Greening Hiatus in Eurasian Boreal Forests Since 1997 Caused by a Wetting and Cooling Summer Climate, J. Geophys. Res. Biogeosciences, 125(9), doi:10.1029/2020JG005662, 2020.

Gatti, L. V., Basso, L. S., Miller, J. B., Gloor, M., Gatti Domingues, L., Cassol, H. L. G., Tejada, G., Aragão, L. E. O. C., Nobre, C., Peters, W., Marani, L., Arai, E., Sanches, A. H., Corrêa, S. M., Anderson, L., Von Randow, C., Correia, C. S. C., Crispim, S. P. and Neves, R. A. L.: Amazonia as a carbon source linked to deforestation and climate change, Nature, 595(7867), doi:10.1038/s41586-021-03629-6, 2021. net $\mathrm{CO} 2$ uptake and growth of a rainforest tree during tropical rainy seasons, Proc. Natl. Acad. Sci. U. S. A., 100(2), doi:10.1073/pnas.0133045100, 2003.

Guan, K., Pan, M., Li, H., Wolf, A., Wu, J., Medvigy, D., Caylor, K. K., Sheffield, J., Wood, E. Photosynthetic seasonality of global tropical forests constrained by hydroclimate, Nat. Geosci., 8(4), doi:10.1038/ngeo2382, 2015.

Hubau, W., Lewis, S. L., Phillips, O. L., Affum-Baffoe, K., Beeckman, H., Cuní-Sanchez, A., Daniels, A. K., Ewango, C. E. N., Fauset, S., Mukinzi, J. M., Sheil, D., Sonké, B., Sullivan, M. J. P., Sunderland, T. C. H., Taedoumg, H., Thomas, S. C., White, L. J. T., Abernethy, K. A., AduBredu, S., Amani, C. A., Baker, T. R., Banin, L. F., Baya, F., Begne, S. K., Bennett, A. C., Benedet, F., Bitariho, R., Bocko, Y. E., Boeckx, P., Boundja, P., Brienen, R. J. W., Brncic, T., Chezeaux, E., Chuyong, G. B., Clark, C. J., Collins, M., Comiskey, J. A., Coomes, D. A., Dargie, G. C., de Haulleville, T., Kamdem, M. N. D., Doucet, J. L., Esquivel-Muelbert, A., Feldpausch, T. R., Fofanah, A., Foli, E. G., Gilpin, M., Gloor, E., Gonmadje, C., Gourlet-Fleury,

398 S., Hall, J. S., Hamilton, A. C., Harris, D. J., Hart, T. B., Hockemba, M. B. N., Hladik, A., Ifo, S.

399 A., Jeffery, K. J., Jucker, T., Yakusu, E. K., Kearsley, E., Kenfack, D., Koch, A., Leal, M. E., 400 Levesley, A., Lindsell, J. A., Lisingo, J., Lopez-Gonzalez, G., Lovett, J. C., Makana, J. R., 401 Malhi, Y., Marshall, A. R., Martin, J., Martin, E. H., Mbayu, F. M., Medjibe, V. P., Mihindou, 402 V., Mitchard, E. T. A., Moore, S., Munishi, P. K. T., Bengone, N. N., Ojo, L., Ondo, F. E., Peh, 403 K. S. H., Pickavance, G. C., Poulsen, A. D., Poulsen, J. R., Qie, L., Reitsma, J., Rovero, F., 404 Swaine, M. D., Talbot, J., Taplin, J., Taylor, D. M., Thomas, D. W., Toirambe, B., Mukendi, J. 
405 T., Tuagben, D., Umunay, P. M., et al.: Asynchronous carbon sink saturation in African and

406 Amazonian tropical forests, Nature, 579(7797), doi:10.1038/s41586-020-2035-0, 2020.

407 IPCC: Special report on carbon dioxide capture and storage, New York., 2005.

408 IPCC: Climate Change 2013: The Physical Science Basis, Contribution of Working Group I,

409 Fifth Assess. Rep. Intergov. Panel Clim. Chang., 2013.

410 IPCC: IPCC 2018 Report: Global Warming of $1.5^{\circ} \mathrm{C}$, in Global Warming of 1,5 C Chapter I., 4112018.

412 IPCC AR6 WGI: Climate Change 2021 The Physical Science Basis., 2021.

413 Jevrejeva, S., Jackson, L. P., Riva, R. E. M., Grinsted, A. and Moore, J. C.: Coastal sea level rise

414 with warming above $2{ }^{\circ} \mathrm{C}$, Proc. Natl. Acad. Sci. U. S. A., 113(47),

415 doi:10.1073/pnas.1605312113, 2016.

416 Jones, N.: Sucking carbon out of the air, Nature, doi:10.1038/news.2008.1319, 2008.

417 Kirchmeier-Young, M. C. and Zhang, X.: Human influence has intensified extreme precipitation

418 in North America, Proc. Natl. Acad. Sci. U. S. A., 117(24), doi:10.1073/pnas.1921628117, 2020.

419 Koven, C., Arora, V., Cadule, P., Fisher, R., Jones, C., Lawrence, D., Lewis, J., Lindsey, K.,

420 Mathesius, S., Meinshausen, M., Mills, M., Nicholls, Z., Sanderson, B., Swart, N., Wieder, W.

421 and Zickfeld, K.: 23rd Century surprises: Long-term dynamics of the climate and carbon cycle

422 under both high and net negative emissions scenarios, Earth Syst. Dyn. Discuss.,

423 doi:10.5194/esd-2021-23, 2021.

424 Lawrence, M. G., Schäfer, S., Muri, H., Scott, V., Oschlies, A., Vaughan, N. E., Boucher, O.,

425 Schmidt, H., Haywood, J. and Scheffran, J.: Evaluating climate geoengineering proposals in the

426 context of the Paris Agreement temperature goals, Nat. Commun., 9(1), doi:10.1038/s41467-

427 018-05938-3, 2018.

428 Leung, D. Y. C., Caramanna, G. and Maroto-Valer, M. M.: An overview of current status of

429 carbon dioxide capture and storage technologies, Renew. Sustain. Energy Rev., 39,

430 doi:10.1016/j.rser.2014.07.093, 2014.

431 Mitchard, E. T. A.: The tropical forest carbon cycle and climate change, Nature, 559(7715),

432 doi:10.1038/s41586-018-0300-2, 2018. 
433 Moore, J. C., Grinsted, A., Guo, X., Yu, X., Jevrejeva, S., Rinke, A., Cui, X., Kravitz, B., 434 Lenton, A., Watanabe, S. and Ji, D.: Atlantic hurricane surge response to geoengineering, Proc.

435 Natl. Acad. Sci. U. S. A., 112(45), doi:10.1073/pnas.1510530112, 2015.

436 Oren, R., Ellsworth, D. S., Johnsen, K. H., Phillips, N., Ewers, B. E., Maier, C., Schäfer, K. V.

437 R., McCarthy, H., Hendrey, G., McNulty, S. G. and Katul, G. G.: Soil fertility limits carbon

438 sequestration by forest ecosystems in a CO2-enriched atmosphere, Nature, 411(6836),

439 doi:10.1038/35078064, 2001.

440 Pan, Y., Birdsey, R. A., Fang, J., Houghton, R., Kauppi, P. E., Kurz, W. A., Phillips, O. L.,

441 Shvidenko, A., Lewis, S. L., Canadell, J. G., Ciais, P., Jackson, R. B., Pacala, S. W., McGuire,

442 A. D., Piao, S., Rautiainen, A., Sitch, S. and Hayes, D.: A large and persistent carbon sink in the 443 world's forests, Science (80-. )., 333(6045), doi:10.1126/science.1201609, 2011.

444 Proctor, J., Hsiang, S., Burney, J., Burke, M. and Schlenker, W.: Estimating global agricultural

445 effects of geoengineering using volcanic eruptions, Nature, 560(7719), doi:10.1038/s41586-018$446 \quad 0417-3,2018$.

447 Realmonte, G., Drouet, L., Gambhir, A., Glynn, J., Hawkes, A., Köberle, A. C. and Tavoni, M.: 448 An inter-model assessment of the role of direct air capture in deep mitigation pathways, Nat.

449 Commun., 10(1), doi:10.1038/s41467-019-10842-5, 2019.

450 Reich, P. B., Sendall, K. M., Stefanski, A., Rich, R. L., Hobbie, S. E. and Montgomery, R. A.: 451 Effects of climate warming on photosynthesis in boreal tree species depend on soil moisture, 452 Nature, 562(7726), doi:10.1038/s41586-018-0582-4, 2018.

453 Riahi, K., van Vuuren, D. P., Kriegler, E., Edmonds, J., O’Neill, B. C., Fujimori, S., Bauer, N., 454 Calvin, K., Dellink, R., Fricko, O., Lutz, W., Popp, A., Cuaresma, J. C., KC, S., Leimbach, M., 455 Jiang, L., Kram, T., Rao, S., Emmerling, J., Ebi, K., Hasegawa, T., Havlik, P., Humpenöder, F., 456 Da Silva, L. A., Smith, S., Stehfest, E., Bosetti, V., Eom, J., Gernaat, D., Masui, T., Rogelj, J., 457 Strefler, J., Drouet, L., Krey, V., Luderer, G., Harmsen, M., Takahashi, K., Baumstark, L., 458 Doelman, J. C., Kainuma, M., Klimont, Z., Marangoni, G., Lotze-Campen, H., Obersteiner, M., 459 Tabeau, A. and Tavoni, M.: The Shared Socioeconomic Pathways and their energy, land use, and 460 greenhouse gas emissions implications: An overview, Glob. Environ. Chang., 42, 461 doi:10.1016/j.gloenvcha.2016.05.009, 2017. 
467 Sellers, P.: Biophysical models of land surface processes. In Climate System Modelling, 468 Trenberth KE (ed.), Cambridge University Press., 1992.

469 Stubblebine, W., Langenheim, J. H. and Lincoln, D.: Vegetative Response to Photoperiod in the 470 Tropical Leguminous Tree Hymenaea courbaril L, Biotropica, 10(1), doi:10.2307/2388100, 4711978.

472 Sullivan, M. J. P., Lewis, S. L., Affum-Baffoe, K., Castilho, C., Costa, F., Sanchez, A. C., 473 Ewango, C. E. N., Hubau, W., Marimon, B., Monteagudo-Mendoza, A., Qie, L., Sonké, B., 474 Martinez, R. V., Baker, T. R., Brienen, R. J. W., Feldpausch, T. R., Galbraith, D., Gloor, M., 475 Malhi, Y., Aiba, S. I., Alexiades, M. N., Almeida, E. C., De Oliveira, E. A., Dávila, E. Á., 476 Loayza, P. A., Andrade, A., Vieira, S. A., Aragão, L. E. O. C., Araujo-Murakami, A., Arets, E. J. 477 M. M., Arroyo, L., Ashton, P., Gerardo Aymard, C., Baccaro, F. B., Banin, L. F., Baraloto, C., 478 Camargo, P. B., Barlow, J., Barroso, J., Bastin, J. F., Batterman, S. A., Beeckman, H., Begne, S. 479 K., Bennett, A. C., Berenguer, E., Berry, N., Blanc, L., Boeckx, P., Bogaert, J., Bonal, D., 480 Bongers, F., Bradford, M., Brearley, F. Q., Brncic, T., Brown, F., Burban, B., Camargo, J. L., 481 Castro, W., Céron, C., Ribeiro, S. C., Moscoso, V. C., Chave, J., Chezeaux, E., Clark, C. J., De 482 Souza, F. C., Collins, M., Comiskey, J. A., Valverde, F. C., Medina, M. C., Da Costa, L., 483 Dančsák, M., Dargie, G. C., Davies, S., Cardozo, N. D., De Haulleville, T., De Medeiros, M. B., 484 Del Aguila Pasquel, J., Derroire, G., Di Fiore, A., Doucet, J. L., Dourdain, A., Droissart, V., 485 Duque, L. F., Ekoungoulou, R., Elias, F., Erwin, T., Esquivel-Muelbert, A., Fauset, S., Ferreira, 486 J., Llampazo, G. F., Foli, E., Ford, A., Gilpin, M., Hall, J. S., Hamer, K. C., Hamilton, A. C., 487 Harris, D. J., Hart, T. B., Hédl, R., et al.: Long-term thermal sensitivity of earth's tropical forests, 488 Science (80-. )., 368(6493), doi:10.1126/science.aaw7578, 2020.

489 Tokarska, K. B. and Zickfeld, K.: The effectiveness of net negative carbon dioxide emissions in 490 reversing anthropogenic climate change, Environ. Res. Lett., 10(9), doi:10.1088/1748-

491 9326/10/9/094013, 2015. 
492 Trenberth, K. E., Fasullo, J. T. and Kiehl, J.: Earth's global energy budget, Bull. Am. Meteorol.

493 Soc., 90(3), doi:10.1175/2008BAMS2634.1, 2009. 